\title{
Long-Term Preservation of Spirillum volutans
}

\author{
E. H. PAULEY and N. R. KRIEG \\ Department of Biology, \\ Virginia Polytechnic Institute and State University, Blacksburg, Virginia 24061
}

\begin{abstract}
Strains of Spirillum volutans, the type species of the genus Spirillum, have not been satisfactorily preserved in the past except by serial transfer. Long-term preservation of such strains can be achieved in liquid nitrogen by the use of dimethyl sulfoxide and a low-salt suspending medium. Glycerol is not satisfactory as a cryoprotective agent.
\end{abstract}

Hylemon et al. (3) recently proposed designation of Spirillum volutans as the type species of the genus Spirillum, with $S$. volutans strain ATCC 19554 (Wells' strain) to serve as the neotype strain. The importance of adequate preservation of type and neotype strains has been stressed in Recommendation 9c of the International Code of Nomenclature of Bacteria (2) as follows: "Bearing in mind the morphological, biochemical, antigenic and virulence changes that may occur as the result of repeated subculture, every precaution should be taken to maintain such cultures with a minimum amount of change." Unfortunately, the only reliable method to date for preservation of the type strain of $S$. volutans has been by repeated subculture. The difficulties experienced with long-term preservation methods involving freezing are likely related to the unusually large size of the organism.

S. volutans ATCC 19554 is an obligate microaerophile, but it can be maintained by weekly transfer in semi-solid $(0.15 \%$ agar) modified-peptone-succinate-salts medium (MPSS) (1) under aerobic conditions with incubation and storage at $30 \mathrm{C}$. From semi-solid stocks, the organism can be cultured in MPSS broth at $30 \mathrm{C}$ provided that the atmosphere within the culture vessel is modified to contain $6 \%$ oxygen: $94 \%$ nitrogen. After 2 months or more of maintenance by serial transfer in semi-solid MPSS medium, the organism may initially exhibit clumping and a poor growth response when transferred to MPSS broth; however, after 7 successive daily transfers in broth, using 1.5 to $2.0 \mathrm{ml}$ of each previous culture as inoculum for $75 \mathrm{ml}$ of medium, the organism again becomes capable of producing high turbidities within $24 \mathrm{~h}$. For preservation, $S$. volutans was inoculated into two $75-\mathrm{ml}$ portions of MPSS broth, using $0.5 \mathrm{ml}$ from an actively growing 24-h-old broth culture as inoculum for each portion. After incubation at $30 \mathrm{C}$ for $24 \mathrm{~h}$, the cells were pooled, harvested at $3,500 \times g$, and washed once with nutrient broth (Difco) to remove excess salts. The use of higher centrifugal forces appeared to damage the cells. The cells were suspended by gentle agitation in $20 \mathrm{ml}$ of nutrient broth containing $10 \%$ dimethyl sulfoxide (DMSO) and were incubated at room temperature $(25 \mathrm{C})$ for 30 min to allow penetration of the cryoprotective agent. The suspension was then dispensed in 1.0-ml samples into NUNC screw-capped plastic vials (2-ml capacity; Vangard International Inc., Red Bank, N. J.). The vials were frozen in a mixture of dry ice and alcohol and then stored by submersion in liquid nitrogen.

Because no satisfactory quantitative plating method has yet been developed for S. volutans, determination of the degree of survival after various periods of storage was accomplished by end-point dilution. Duplicate vials were thawed by immersion in water at $30 \mathrm{C}$, and the contents were diluted in decimal series in MPSS broth. From each dilution, 0.1-ml samples were deposited on the surface of each of four tubes of semisolid (0.15\% agar) MPSS medium (each 20 by $125 \mathrm{~mm}$ loosely screw-capped tube contained $10 \mathrm{ml}$ of semisolid medium). Semisolid medium will permit the growth of $S$. volutans without the use of a $6 \%$ oxygen atmosphere. After aerobic incubation of the tubes for 12 days at $30 \mathrm{C}$, the proportion of tubes showing a positive growth response in each set of four was determined, and the purity of the cultures was established by microscopic examination. From the data, the $50 \%$ titration end points and the viable cells $5_{50} / \mathrm{ml}$ were calculated (see Table 1). With DMSO as the cryoprotective agent, a decrease in titer of only $1 \log$ occurred at the end of 4 weeks, with no further decrease evident even at the end of 6 months; furthermore, when vial contents were 
TABLE 1. Survival of S. volutans ATCC 19554 in liquid nitrogen with $15 \%$ glycerol or $10 \%$ DMSO as a cryoprotective agent

\begin{tabular}{|c|c|c|}
\hline \multirow[b]{2}{*}{ Time of titration } & \multicolumn{2}{|c|}{ Viable cells $_{5_{0}} / \mathrm{ml}^{a}$} \\
\hline & Glycerol & DMSO \\
\hline $\begin{array}{l}\text { Immediately prior to } \\
\text { freezing } \ldots \ldots \ldots\end{array}$ & $3 \times 10^{6}$ & $3 \times 10^{7}$ \\
\hline 2-Weeks storage $\ldots$ & 0 & $3 \times 10^{7}$ \\
\hline 4-Weeks storage .... & 0 & $3 \times 10^{6}$ \\
\hline 6-Months storage $\ldots \ldots \ldots$ & 0 & $3 \times 10^{6}$ \\
\hline
\end{tabular}

${ }^{a}$ By end point dilution method.

examined by darkfield microscopy immediately after thawing, a high proportion of coordinated motile cells was observed in every case. With $15 \%$ glycerol as the cryoprotective agent, no cells survived at the end of 2 weeks of storage, and no motile cells could be observed when the vials were thawed. However, spirilla other than $S$. volutans can be preserved quite satisfactorily with glycerol (4). We conclude that long-term preservation of $S$. volutans can be achieved in liquid nitrogen with DMSO serving as a suitable cryoprotective agent.

For routine preparation of cultures from the frozen spirilla, the following procedure has yielded consistently satisfactory results in our laboratory. A 75-ml amount of MPSS broth is sterilized at $121 \mathrm{C}$ for $15 \mathrm{~min}$ in a $250-\mathrm{ml}$ side-arm filter flask. The side arm is equipped with a rubber hose, screw-clamp, and cotton filter, while the mouth of the flask is closed tightly with a rubber stopper into which is fitted a glass tube having a serum-bottle stopper. During sterilization, the side arm is not clamped off but should be closed immediately after sterilization to prevent extensive aeration of the medium. The medium can be stored for long periods under such conditions; however, storage in bright light, e.g., near a window, results in the formation of inhibitory factors, possibly peroxides, in the medium. Before inoculation, the atmosphere in the flask is modified by evacuating via the side-arm and refilling with a mixture of $6 \%$ oxygen: $94 \%$ nitrogen. Ampoules of frozen spirilla are thawed as described above, and the contents are transferred with a syringe and needle into the flask through the serum-bottle stopper. The flask is incubated at $30 \mathrm{C}$ for $24 \mathrm{~h}$. Two or three transfers should be made in MPSS broth, using $1.0 \mathrm{ml}$ from each previous culture as inoculum, to obtain a vigorous culture.

\section{REPRINT REQUESTS}

Address reprint requests to: Esther H. Pauley, Department of Biology, Virginia Polytechnic Institute and State University, Blacksburg, Virginia 24061.

\section{LITERATURE CITED}

1. Caraway, B. H., and N. R. Krieg. 1972. Uncoordination and recoordination in Spirillum volutans. Can. J. Microbiol. 18:1749-1759.

2. Editorial Board of the Judicial Commission of the International Committee on Nomenclature of Bacteria. 1966. International code of nomenclature of bacteria. Int. J. Syst. Bacteriol. 16:459-490.

3. Hylemon, P. B., J. S. Wells, Jr., J. H. Bowdre, T. O. MacAdoo, and N. R. Krieg. 1973. Designation of Spirillum volutans Ehrenberg 1832 as type species of the genus Spirillum Ehrenberg 1832 and designation of the neotype strain of $S$. volutans. Int. J. Syst. Bacteriol. 23:20-27.

4. Hylemon, P. B., J. S. Wells, Jr., N. R. Krieg, and H. W. Jannasch. 1973. The genus Spirillum: a taxonomic study. Int. J. Syst. Bacteriol. 23:340-380. 